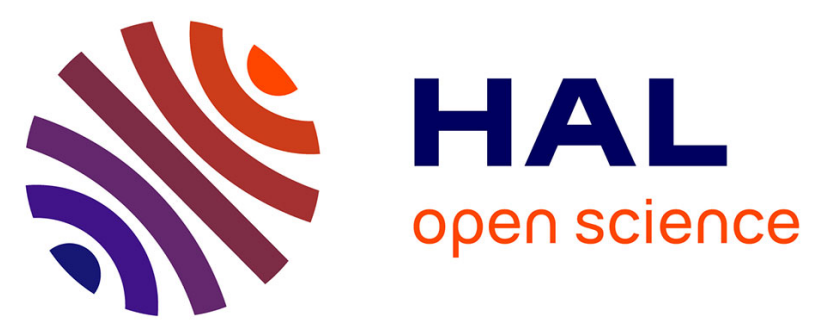

\title{
Assessment of Isoprostanes in Human Plasma: Technical Considerations and the Use of Mass Spectrometry
} Yiu Yiu Lee, Jean-Marie Galano, Camille Oger, Claire Vigor, Guillaume Reversat, Jérôme Roy, Jean-Yves Le Guennec, Thierry Durand, Jetty Chung-Yung Lee

\section{To cite this version:}

Yiu Yiu Lee, Jean-Marie Galano, Camille Oger, Claire Vigor, Guillaume Reversat, et al.. Assessment of Isoprostanes in Human Plasma: Technical Considerations and the Use of Mass Spectrometry. Lipids, 2016, 51 (11), pp.1217 - 1229. 10.1007/s11745-016-4198-x . hal-01784397

\section{HAL Id: hal-01784397 \\ https://hal.umontpellier.fr/hal-01784397}

Submitted on 6 Dec 2019

HAL is a multi-disciplinary open access archive for the deposit and dissemination of scientific research documents, whether they are published or not. The documents may come from teaching and research institutions in France or abroad, or from public or private research centers.
L'archive ouverte pluridisciplinaire HAL, est destinée au dépôt et à la diffusion de documents scientifiques de niveau recherche, publiés ou non, émanant des établissements d'enseignement et de recherche français ou étrangers, des laboratoires publics ou privés. 


$\begin{array}{ll}\text { LOQ } & \text { Limit of quantification } \\ \text { MECP2 } & \text { Methyl-CpG-binding protein 2 } \\ \text { MRM } & \text { Multiple reaction monitoring } \\ \text { MS } & \text { Mass spectrometry } \\ m / z & \text { Mass over charge ratio } \\ \text { NeuroP } & \text { Neuroprostane } \\ \text { NICI } & \text { Negative-ion chemical ionization } \\ \text { PoAF } & \text { Postoperative atrial fibrillation } \\ \text { PUFA } & \text { Polyunsaturated fatty acid } \\ \text { Q1 } & \text { Precursor/parent ion } \\ \text { Q3 } & \text { Fragmented/daughter ion } \\ \text { RIA } & \text { Radioimmunoassay } \\ \text { SIM } & \text { Selected ion monitoring } \\ \text { S/N } & \text { Signal-to-noise ratio } \\ \text { SPE } & \text { Solid phase extraction } \\ \text { TOF } & \text { Time-of-flight }\end{array}$

\section{Introduction}

The discovery of isoprostanes (IsoPs) by Morrow and coworkers in 1990 [1] unfolded a whole new area of interest in lipid molecule research. Over the next two and a half decades, enormous amounts of work, including the biosynthesis, chemical total synthesis, and biological relevance of IsoPs, have been extensively published and reviewed [2-4]. The generation of IsoPs is through non-enzymatic oxygenation of polyunsaturated fatty acids (PUFA) initiated by free radical attack, leading to lipid peroxidation [5]. The most classic example of IsoP biomolecules is the family of $\mathrm{F}_{2}$-isoprostanes ( $\mathrm{F}_{2}$-IsoPs), particularly the isomer $15-\mathrm{F}_{2 \mathrm{t}^{-}}$ isoprostane $\left(15-\mathrm{F}_{2 \mathrm{t}} \mathrm{-I}\right.$ soP). The $15-\mathrm{F}_{2 \mathrm{t}}$-IsoP was the first and most widely studied IsoP among the family of IsoPs, and the measurement of $15-\mathrm{F}_{2 \mathrm{t}}$-IsoP is considered a robust biomarker for accessing oxidative stress status in vivo [6]; overproduction of IsoPs is generally regarded as disadvantageous to health. Indeed, numerous metabolic disorders and pathophysiological diseases such as cardiac ischemiareperfusion [7, 8], atherosclerosis [9], neurodegenerative diseases [10-12], and cancer [13] are frequently associated with elevated plasma $\mathrm{F}_{2}$-IsoPs.

IsoPs are quantifiable from solid specimens like tissues and cells, or body fluids such as urine [14], plasma/serum [15], or saliva [16] and bronchial lavages [17]. Comparatively, body fluids are much more acquirable than tissues from healthy individuals to access their in vivo oxidative status. The choice of specimen sampling, for example plasma versus urine, is important as it might reveal different rate of IsoP metabolism [18]. Although urine is a noninvasive sampling method and readily available, measurement of $15-\mathrm{F}_{2 \mathrm{t}}$-IsoP in plasma provides a sensitive index in overall systemic oxidant injury that presumably derived from all tissues in the body. This is unlike the metabolised
$\mathrm{F}_{2}$-IsoPs found in urine that are in part derived from the kidney, jeopardising the sensitivity and specificity of urinary $\mathrm{F}_{2}$-IsoPs as a systemic oxidant injury biomarker [18]. As such, the IsoPs measurable in human plasma will be the focus of this article. Plasma sampling, however, possesses a problem of developing artefacts of arachidonic acid autoxidation if samples are not processed or stored properly. To overcome this problem, butylated hydroxytoluene (BHT) and indomethacin [19] is recommended to be added to the plasma before storing them in the deep freezer of $-80{ }^{\circ} \mathrm{C}$, but not $-20^{\circ} \mathrm{C}$ as storing in such temperature leads to the production of $\mathrm{F}_{2}$-IsoP artefacts. Addition of BHT and indomethacin in the plasma serve as free radical scavenger and cyclooxygenase inhibitor respectively, preventing ex vivo non-enzymatic and enzymatic oxidation to occur [20].

Measurement of plasma IsoPs often start off with lipid extractions commonly employed or modified from established methods, e.g. Folch [21] or Bligh and Dyer [22] methods or protein precipitation with high content of polar solvent. This is followed by further purification, such as solid phase extraction (SPE) [23], thin layer chromatography (TLC) [24] and/or high performance liquid chromatography (HPLC) [25]. Subsequently, measurements of IsoPs and their precursors are widely dependent on the use of mass spectrometry (MS) coupled with either gas chromatography (GC) or liquid chromatography (LC). The choice of gas or liquid chromatographic method to couple with MS however remains as a controversial argument, as both have their respective pros and cons.

This article reviews the technical and biological relevance of quantifying isoprostanoids in human blood plasma. Additionally, we will highlight some important points to take into consideration when choosing which chromatographic separation method to employ in conjunction with MS, i.e. GC-MS(/MS) or LC-MS(/MS).

\section{Biological Relevance of Quantifying Isoprostane Molecules}

Isoprostanes are prostaglandin-like molecules that are produced independently and non-enzymatically from various PUFA, most commonly from alpha-linolenic acid (ALA), arachidonic acid (ARA), adrenic acid (AdA), eicosapentaenoic acid (EPA) and docosahexaenoic acid (DHA). Different classes of IsoPs were discovered with different functional groups on their respective cyclopentane ring structure [26]. For simplicity and coherence of this article, only F-ring IsoPs will be discussed as they are highly abundant in vivo and the most well studied. Because of the highly unsaturated nature of PUFAs and to the formation mechanism of IsoP, a substantial amount of racemic regioisomer and diastereisomer of IsoP molecules can be derived from the same precursors, leading to a vast range of 
possible biomolecules being generated [27]. While PUFAs are provided as substrate for peroxidation, they have different rates of oxidation. The most oxidizable PUFA appears to be DHA, due to its great number of double bonds. Interestingly, the biosynthesis of metabolically and chemically stable IsoPs is realised primarily in situ in the phospholipid bed. The PUFA esterified in phospholipids are oxidized to IsoPs and released into free form by phospholipase $A_{2}$ $\left(\mathrm{PLA}_{2}\right)$ hydrolysis [28]. Therefore, IsoP can be quantified in human plasma as free or esterified forms, or even total IsoPs (free plus esterified) [18]. One common approach to differentiate esterified IsoPs from the free ones is via in vitro hydrolysis. This is accomplished by the introduction of concentrated alkaline solution, such as potassium hydroxide, to the sample for saponification after total lipid extraction. Alternatively, the addition of exogenous PLA into the sample, prior to total lipid extraction by organic solvents, is able to liberate all the esterified IsoPs [29]. While both methods are commonly employed for the measurement of esterified IsoPs, the use of PLA 2 overcomes the structural alteration on the IsoP as caused by saponification, but may be costly in practice.

\section{$F_{1}$-Phytoprostanes $\left(F_{1}\right.$-PhytoPs $)$}

$\mathrm{F}_{1}$-PhytoPs are oxygenated biomolecules from its precursor, $\alpha$-linolenic acid (ALA) and were first discovered in plants by Parchmann and Mueller [30], which theoretically yield up to two regioisomers ( 9 and 16 series) and 32 diastereoisomers. ALA is also the precursor for the generation of longer and higher degree of unsaturated PUFAs such as EPA and DHA, which are important for proper foetal development and health maintenance [31]. Mammals do not endogenously produce ALA, but it is found in plants and algae therefore, the mode of acquisition is only possible through diet. Absorbed ALA and PhytoPs are transported in plasma in the conjugated form and excreted as the free form in urine. In addition, $\mathrm{F}_{1}-\mathrm{PhytoP}$ is increased in humans with increased consumption of ALArich flaxseeds or vegetable oil [32]. Mediterranean diets that are plentiful in ALA-rich vegetables, nuts, and seeds might contribute considerable benefits to health such as preventing cardiovascular disease, anti-inflammation and neuroprotection [33-35]. However, these health benefits may also be due to the PhytoPs found in foods such as rapeseed, olives and almonds, for example $[33,36]$.

\section{$F_{2}$-Isoprostanes $\left(F_{2}\right.$-IsoPs $)$}

Arachidonic acid (ARA), an n-6 PUFA, is one of the most abundant PUFAs in the cell membrane. Large amount of IsoPs molecules are generated from ARA, and the majority of them are from the F-ring group therefore, are termed $\mathrm{F}_{2}$-IsoPs. A total of 64 compounds from four regioisomers
(5-, 12-, 8-, and 15-series) can be formed theoretically [5]. Because of the high amount of ARA on the cell membrane of most cell types, production of $15-\mathrm{F}_{2 \mathrm{t}}$-IsoP would be increased when challenged by free radical attacks, leading to oxidative stress [37]. Therefore, measurement of $15-\mathrm{F}_{2 \mathrm{t}^{-}}$ IsoP has been generally used as an indicator for overall in vivo oxidative stress status in the biological systems [38]. Also, another reason in qualifying it to be suitable candidate for oxidant status biomarker is the stability and robustness of this molecule. Elevation of total $\mathrm{F}_{2}$-IsoPs in the plasma is often associated with wide range of metabolic disorders, such as in patients with chronic haemodialysis [39], diabetes [40] and atherosclerosis [41]. Apart from being a biomarker, $15-\mathrm{F}_{2 \mathrm{t}}$-IsoP also exerts its biological role as vasoconstrictor in most vascular beds, including but not limited to brain, heart, lung, and kidney [42]. Also, it is a ligand for thromboxane receptor and modifies platelet shape and aggregation in human plasma [43, 44].

\section{$F_{2}$-dihomo-isoprostanes $\left(F_{2}\right.$-dihomo-IsoP)}

$\mathrm{F}_{2}$-dihomo-IsoP is the latest IsoP family to be discovered to date. Free radical attack on adrenic acid (AdA) generate $\mathrm{F}_{2}$-dihomo-IsoPs molecules, which share many structural similarities to $\mathrm{F}_{2}$-IsoPs such as the ring structure, hydroxyl moieties and numbers of isomers [45]. The only difference is that $\mathrm{F}_{2}$-dihomo-IsoPs contains two additional methylene groups than $\mathrm{F}_{2}$-IsoP, weighting 28 Da more. AdA is highly localized in the myelin (brain white matter) and accounts for the third highest PUFA concentration in the brain after ARA and DHA. White matter is commonly damaged in the event of neuro-oxidative stress and a significant increase of $\mathrm{F}_{2}$-dihomo-IsoPs is found in the brains of patients with degenerative diseases. The levels of $\mathrm{F}_{2}$-dihomo-IsoPs in these oxidative injured white matters have greater extent than IsoPs derived from ARA and DHA [46]. Thus, $\mathrm{F}_{2}-$ dihomo-IsoP was proposed as the biomarker for the free radical damage of myelin as observed in the patients with Rett syndrome. Rett syndrome is a congenital condition predominantly found in female patients that is caused by DNA mutation in the gene encoded for methyl-CpG-binding protein 2 (MECP2) [47]. The alterations in MECP2 expression have an impact on the CNS plasticity, leading to learning and memory dysfunction. Although oxidative stress has been shown to be involved in Rett syndrome [48], it remains unclear if it is the cause or the consequence of the pathogenesis [49]. Nonetheless, studies on Rett syndrome patients showed elevated plasma $\mathrm{F}_{2}$-dihomo-IsoPs, which further affirm its suitability as a reliable biomarker for oxidative damage of brain white matter [50, 51]. To date, little is known about $\mathrm{F}_{2}$-dihomo-IsoPs molecules and they are generating great interest in the possible role(s) and mechanism of its pathogenesis in neuronal diseases. 


\section{$F_{3}$-isoprostanes $\left(F_{3}\right.$-IsoP $)$}

Lipid peroxidation of eicosapentaenoic acid (EPA) converts to the 6-series of $\mathrm{F}_{3}$-IsoPs regioisomers [52]. Physiologically, only a small amount of $\mathrm{F}_{3}$-IsoPs molecules are expected to form in vivo since the level of endogenous EPA is relatively low. Dietary supplementation can compensate the EPA level, and DHA can retro-convert to EPA in the metabolism [53]. As EPA is the most abundant PUFA in fish oil, the beneficial effects of fish oil supplementation are generating great interest. Supplementation of fish oil markedly increased the production of $\mathrm{F}_{3}$-IsoPs in mice and showed to be anti-inflammatory [54]. Simultaneously, levels of pro-inflammatory $\mathrm{F}_{2}$-IsoPs were highly reduced due to suppression of ARA by EPA [54]. Furthermore, it was discovered that a specific type of $\mathrm{F}_{3}$-IsoPs had an effect on cardiac cell arrhythmia [55] and 5-epi-5- $\mathrm{F}_{3 \mathrm{t}}$-IsoP was reported to reduce $\mathrm{K}^{+}$-induced $\left[{ }^{3} \mathrm{H}\right]_{\mathrm{D} \text {-aspartate release in }}$ the bovine retina, which was in part associated with the activation of pre-junctional prostanoid EP1-receptors [56]. Only a handful of studies examined $\mathrm{F}_{3}$-IsoPs in plasma. A recent study on the effects of fish oil supplementation in postoperative atrial fibrillation (PoAF) patients showed $\mathrm{F}_{3}$ IsoPs levels in plasma and urine collected before and right after cardiac surgery and 2 days after the surgery. In the report, an association was found with urinary $\mathrm{F}_{3}$-IsoP concentration, but not plasma with higher risk of PoAF development [57]. Further, supplementation of fish oil to Rett syndrome patients lowered plasma $\mathrm{F}_{3}$-IsoP levels and the patients showed strengthened motor related signals [58].

\section{$F_{4}$-neuroprostanes $\left(F_{4}\right.$-NeuroPs $)$}

Neuroprostanes (NeuroPs) molecules are termed based on the initial discovery of IsoP-like molecules from docosahexaenoic acid (DHA), which is highly enriched in the neurons, but not in other tissues. Eight racemic regioisomers of $\mathrm{F}_{4}$-NeuroPs (4-, 7-, 10-, 11-, 13-, 14-, 17-, and 20 -series) can be formed from DHA totalling $128 \mathrm{com}-$ pounds [59]. Comparatively, due to the large number of double bonds, DHA is the most susceptible PUFA to be oxidized. The high abundance of DHA in the brain suggests $\mathrm{F}_{4}$-NeuroPs as the optimal biomarker for neuronal oxidant injury [60]. Indeed, high levels of $\mathrm{F}_{4}$-NeuroPs were detected in brain tissues and cerebrospinal fluids of Alzheimer's disease patients, but were not associated with plasma or urine levels [61]. This might suggest that only neural DHA are oxidised and/or affected in brain-related diseases. The supplementation of fish oil in Rett syndrome patients however, has shown to reduce plasma $F_{4}$-NeuroP concentration with improvement in clinical severity such as non-verbal communication [58]. Thus, the concentration of plasma $\mathrm{F}_{4}$-NeuroP in Rett syndrome patients might reveal the severity of their conditions. In addition, plasma $\mathrm{F}_{4}-\mathrm{Neu}-$ roPs also appeared to be a potential predictor for cigarette smokers [62] and pre-eclampsia [63]. These indicate that the measurement of plasma $\mathrm{F}_{4}$-NeuroPs might also serve as an overall health index for an individual. In order to study the biological role of $\mathrm{F}_{4}$-NeuroPs molecules in vivo, pure chemical standards are needed. However, $\mathrm{F}_{4}$-NeuroP standards are currently not commercially available. Ironically, despite the synthetic work effort by research groups like Durand, Rokach, Taber, and Cha whose successfully synthesized numerous series of $F_{4}$-NeuroPs [64-68], the molecular activity of $\mathrm{F}_{4}$-NeuroPs remains largely unexplored. Not until recently, the anti-arrhythmic property of $4(R S)-4-\mathrm{F}_{4 \mathrm{t}}-\mathrm{NeuroP}$ biomolecule, one of the eight isomers of $\mathrm{F}_{4}$-NeuroPs was discovered [55] in post-myocardial infarcted mice, opening an area of research on the beneficial effects of autoxidized PUFA metabolites.

\section{Measurement of Isoprostanes in Human Plasma}

Plasma IsoPs are commonly detected via mass spectrometry (MS), coupling to either gas chromatography (GC) or liquid chromatography (LC), and to a lesser extent by immunological methods, such as radioimmunoassay (RIA) and enzyme-linked immunoassay (ELISA). Commercial RIA and ELISA kits are known to provide a high speed, relatively low-cost, high sensitivity, and strong specificity method for IsoPs analysis. Specifically, for $15-\mathrm{F}_{2 \mathrm{t}}$-IsoP molecule measurements, quantification of ligand concentration is inversely related to radioactivity for RIA, while direct fluorescent intensity is inferred to estimate the antigen amount present for ELISA. Both types of immunological assays rely on the use of specific antibody, but they tend to have positive bias results due to polyclonal antibody reacting with other compounds. A recent study by Klawitter et al. [15] compared some ELISA kits developed by Assay Designs (USA), Cayman Chemicals (USA), and Oxford Biomedical Research (USA) with LC-MS/MS on their $15-\mathrm{F}_{2 \mathrm{t}}$-IsoP detection performance using human plasma and urine. These immunological assay kits were reported to generate a higher quantity of $15-\mathrm{F}_{2 \mathrm{t}}$-IsoP than those measured by LC-MS/MS, overestimating the levels of $15-\mathrm{F}_{2 \mathrm{t}^{-}}$ IsoP, particularly in plasma samples. The quantities measured were also disturbingly deviated from one ELISA kit to another, suggesting that concentrations measured from different ELISA kits were not comparable in parallel [15].

On the contrary, the use of MS overcomes such problems and offers fast, genuinely high sensitivity and specificity method for high throughput IsoPs quantification. Although the use of MS instrument is robust, it requires high cost in maintenance and trained personnel to operate the machine. As a consequence, laboratories might be forced to rely on immunological assay kits. Numerous studies have been 
published for the detection of IsoPs (mainly on $15-\mathrm{F}_{2}$-IsoPs molecule), using either GC or LC coupled to the MS technique (Tables 1, 2). Measurement of human plasma IsoPs in GC-MS was first developed by Morrow and co-workers using negative ion chemical ionization (NICI) mode [5] and was widely adapted and modified by others. Subsequently, with the advances in LC coupled MS techniques, researchers begun to investigate the possibility of separating IsoPs using an analytical column, usually $\mathrm{C} 18$ reverse phase column. The main difference in using LC to GC is the need to chemically derivatize the purified sample for the latter, which will be discussed later, before subjecting it to GC/ MS or GC-MS/MS. Alternatively, some scientists might by pass the chromatographic separation step and perform direct infusion-based MS to acquire cellular lipidome data on a global scale. However, it is generally not usable for the detection and quantification of low abundance lipids, such as IsoPs, because of the interference from complex higher lipids and extracted matrices [69]. This method is usually employed for lipid molecular species analysis and will not be discussed further.

A wide variety of mass spectrometers used in IsoPs quantification are available in the market. They range in different ionization mode like electrospray ionization (ESI) or atmospheric-pressure chemical ionization (APCI) and mass analysers such as quadrupole, time-of-flight (TOF), and orbitrap. Each has its own merits and demerits depending on the intended purpose, but is not explicitly mentioned here. Rather, the use of single quadrupole or triple quadrupole is what needs to be considered for IsoP measurement. Single MS detection methods such as GC-MS and LC-MS usually report the exact masses of injected analytes over retention time, while MS/MS, as in GC-MS/MS or LC-MS/MS, monitors the precursor (parent) ions (Q1) and fragmented (daughter) ions (Q3) of the molecule over retention time, thus improving the selectivity and precision in detecting targeted IsoPs. The use of MS/MS is particularly useful in detecting interested targets in complex matrices such as plasma at low levels, because the monitoring of Q1 and Q3 transition pair ions further confirms on the target identity among other analytes that might share the same Q1 mass ion. Notably, the selected ion monitoring (SIM) of all $\mathrm{F}_{2}$-IsoP isomers in LC-MS typically use $\mathrm{m} / z, 353$ but in order to identify which $\mathrm{F}_{2}$-IsoP isomers are present in the sample, LC-MS/MS using multiple reaction monitoring (MRM) can further yield for example $\mathrm{m} / \mathrm{z}, 353 \rightarrow 193$ for $15-\mathrm{F}_{2 \mathrm{t}}$-IsoP and $m / z 353 \rightarrow 115$ for $5-\mathrm{F}_{2 \mathrm{t}}$-IsoP [14]. Multiple pairs of transition mass ions can be used in MRM. Typically, the transition mass ions were deduced by compound optimization of respective individual commercial

Table 1 Summary of highly cited (>50) articles reporting on human plasma isoprostanes detection using gas chromatography-mass spectrometry (GC-MS)

\begin{tabular}{|c|c|c|c|c|c|c|c|c|}
\hline Study & $\begin{array}{l}\text { Sample purifica- } \\
\text { tion }\end{array}$ & $\begin{array}{l}\text { Derivatization } \\
\text { agent }\end{array}$ & $\begin{array}{l}\text { Mass spectrom- } \\
\text { eter (company) }\end{array}$ & $\begin{array}{l}\text { Isoprostanoids } \\
\text { detected }\end{array}$ & $m / z$ & $\begin{array}{l}\text { Levels detected } \\
(\mathrm{pg} / \mathrm{mL})\end{array}$ & $\begin{array}{l}\text { Limit of detec- } \\
\text { tion }(\mathrm{pg} / \mathrm{mL})\end{array}$ & References \\
\hline Control & $\begin{array}{l}\text { SPE: C18 } \\
\text { Sep-Pak; } \\
\text { and HPLC: } \\
\text { LiChrospher } \\
100 \text { RP-18 }\end{array}$ & $\begin{array}{l}\text { BSTFA + } 1 \% \\
\text { TMCS }\end{array}$ & $\begin{array}{r}\text { HP 5989B } \\
\text { (Agilent) }\end{array}$ & Total $\mathrm{F}_{2}$-IsoPs & 569 & $337.5 \pm 13.5^{\mathrm{a}}$ & 250 & [82] \\
\hline Control & $\begin{array}{l}\text { TLC: 60ALK- } \\
\text { 6Dplates; and } \\
\text { SPE: C18 } \\
\text { Sep-Pak }\end{array}$ & BSTFA + DMF & $\begin{array}{l}\text { Incos 50B } \\
\text { (Finnigan) }\end{array}$ & Total $\mathrm{F}_{2}$-IsoPs & 514 & $15 \pm 4.9$ & N.A. & [20] \\
\hline Control & $\begin{array}{l}\text { SPE: C18 Sep- } \\
\text { Pak }+\mathrm{NH}_{2} \\
\text { cartridge }\end{array}$ & $\begin{array}{l}\text { BSTFA + } 1 \% \\
\text { TMCS }\end{array}$ & $\begin{array}{c}\text { VG70SEQ } \\
\text { (Fisons) }\end{array}$ & $15-\mathrm{F}_{2 \mathrm{t}}$-IsoP & 569 & $112 \pm 54$ & 10 & [83] \\
\hline $\begin{array}{l}\text { Control renal } \\
\text { disease }\end{array}$ & $\begin{array}{l}\text { HPLC: amino } \\
\text { column, varian } \\
\text { Associates }\end{array}$ & $\begin{array}{l}\text { BSTFA }+1 \% \\
\text { TMCS }\end{array}$ & $\begin{array}{c}\text { Trio } 1000 \text { (VG } \\
\text { Instruments) }\end{array}$ & Total $\mathrm{F}_{2}$-IsoPs & 569 & $\begin{array}{l}0.3 \\
2.5\end{array}$ & 50 & {$[25]$} \\
\hline Control & SPE: MAX & $\begin{array}{l}\text { BSTFA + } 1 \% \\
\text { TMCS }\end{array}$ & $\begin{array}{c}\text { HP } 5973 \mathrm{~N} \\
\text { (Agilent) }\end{array}$ & Total $\mathrm{F}_{2}$-IsoPs & 569 & $0.45 \pm 0.26$ & 22 & [84] \\
\hline Control & SPE: MAX & $\begin{array}{l}\text { BSTFA + } 1 \% \\
\text { TMCS }\end{array}$ & $\begin{array}{l}\text { HP } 5973 \text { (Agi- } \\
\text { lent) }\end{array}$ & Total $\mathrm{F}_{2}$-IsoPs & 569 & $0.239 \pm 0.021$ & 37 & {$[85]$} \\
\hline
\end{tabular}

Keywords searched on the Web of Science (Thomson Reuters): isoprostane, plasma, gas chromatography

BSTFA N,O-bis(trimethylsilyl)trifluoroacetamide, TMCS trimethylchlorosilane, DMF dimethylformamide, TLC thin layer chromatography, SepPak $\mathrm{C} 18$ octadecylsilane cartridge, $\mathrm{NH}_{2}$ aminopropyl cartridge, $\mathrm{MAX}$ mixed anionic exchange, $N . A$. not reported

${ }^{\text {a }}$ Mathematical conversion to match the unit 
Table 2 Summary of highly cited method development articles reporting on plasma isoprostanes detection using liquid chromatography-mass spectrometry (LC-MS/MS)

\begin{tabular}{|c|c|c|c|c|c|c|c|c|}
\hline Study & $\begin{array}{l}\text { Sample purifica- } \\
\text { tion }\end{array}$ & Column & $\begin{array}{l}\text { Mass spec- } \\
\text { trometer } \\
\text { (company) }\end{array}$ & $\begin{array}{l}\text { Isoprostanoids } \\
\text { detected }\end{array}$ & SIM/MRM & $\begin{array}{l}\text { Levels detected } \\
(\mathrm{pg} / \mathrm{mL})\end{array}$ & $\begin{array}{l}\text { Limit of detec- } \\
\text { tion }(\mathrm{pg} / \mathrm{mL})\end{array}$ & References \\
\hline Control & HPLC: XDB-C8 & $\mathrm{C} 18$ & $\begin{array}{l}\text { QTRAP } 4000 \\
\text { (ABSciex) } \\
\text { QTRAP 5000 } \\
\text { (ABSciex) }\end{array}$ & $\begin{array}{l}\text { Free } 15-\mathrm{F}_{2 \mathrm{t}^{-}} \\
\quad \text { IsoP } \\
\text { Free } 15-\mathrm{F}_{2 \mathrm{t}^{-}} \\
\quad \text { IsoP }\end{array}$ & $\begin{array}{l}353 / 193 \\
353 / 193\end{array}$ & $3-25$ & $\begin{array}{l}10 \\
2.5\end{array}$ & {$[70]$} \\
\hline $\begin{array}{l}\text { Non-smokers } \\
\text { Smokers }\end{array}$ & $\begin{array}{l}\text { SPE: Empore } \\
\text { disk cartridge; } \\
0.45 \mu \mathrm{m} \text { filters }\end{array}$ & $\mathrm{C} 8$ & $\begin{array}{l}\text { MStation } 700 \\
(\text { JEOL })\end{array}$ & Total $\mathrm{F}_{2}$-IsoPs & $\begin{array}{l}353.24 \\
353.24\end{array}$ & $\begin{array}{l}42 \pm 2 \\
46 \pm 2\end{array}$ & 20 & {$[86]$} \\
\hline $\begin{array}{l}\text { Non-smokers } \\
\text { Smokers }\end{array}$ & $\begin{array}{l}\text { LLE: ethyl } \\
\text { acetate:hexane } \\
(3: 1)\end{array}$ & C18 & $\begin{array}{l}\text { QTRAP } 3000 \\
\text { (ABSciex) }\end{array}$ & $\begin{array}{l}15-\mathrm{F}_{2 \mathrm{t}^{-}} \mathrm{IsoP} \\
15-e p i-15-\mathrm{F}_{2 \mathrm{t}^{-}} \\
\text {IsoP } \\
15-\mathrm{F}_{2 \mathrm{t}^{-} \mathrm{IsoP}} \\
15-e p i-15-\mathrm{F}_{2 \mathrm{t}^{-}} \\
\quad \text { IsoP }\end{array}$ & $353 / 193$ & $\begin{array}{l}82 \pm 23 \\
108 \pm 32 \\
78 \pm 27 \\
121 \pm 35\end{array}$ & N.A. & [87] \\
\hline Healthy control & $\begin{array}{l}\text { IAC: Isoprostane } \\
\text { affinity column }\end{array}$ & C18 & $\begin{array}{c}\text { Surveyor MSQ } \\
\text { (Finnigan) }\end{array}$ & Total $\mathrm{F}_{2}$-IsoPs & 353.2 & 37.6 & 0.5 & [88] \\
\hline Control & HPLC: XDB-C8 & C18 & $\begin{array}{l}\text { QTRAP 5000 } \\
\text { (ABSciex) }\end{array}$ & $\begin{array}{l}\text { Free } 15-\mathrm{F}_{2 \mathrm{t}^{-}} \\
\text {isoP }\end{array}$ & $353 / 193$ & $21.1 \pm 27.9$ & 2.5 & [15] \\
\hline Control & $\begin{array}{l}\text { 7-mm cellulose } \\
\text { filter; protein } \\
\text { precipitated }\end{array}$ & $\mathrm{C} 18$ & $\begin{array}{l}\text { QTRAP } 4000 \\
\text { (ABSciex) }\end{array}$ & $15-\mathrm{F}_{2 \mathrm{t}} \mathrm{IsoP}$ & $353.1 / 193.2$ & N.A. & $1.3^{\mathrm{a}}$ & [89] \\
\hline Control & $\begin{array}{l}\text { SPE: } 100 \mathrm{mg} \\
\text { C18 EC }\end{array}$ & $\mathrm{ABZ}+$ Plus & $\begin{array}{l}\text { QTRAP } 4000 \\
\text { (ABSciex) }\end{array}$ & $15-\mathrm{F}_{2 \mathrm{t}}$-IsoP & $353.4 / 197.1$ & $40-170$ & 4 & {$[90]$} \\
\hline
\end{tabular}

Keywords searched on the Web of Science (Thomson Reuters): isoprostane, plasma, liquid chromatography

$H P L C$ high performance liquid chromatography, $S P E$ solid phase extraction, $L L E$ liquid-liquid extraction, IAC immune-affinity column, $N . A$. not reported

${ }^{a}$ Mathematical conversion to match the unit

standards performed by the spectrometer using direct infusion through a syringe pump. Therefore, one is required to optimize all the target standards of interests for MS/MS settings, individually, before sample analysis.

In addition, to quantify accurately the absolute amount of target molecules, deuterated internal standards are commonly added in sample preparation or extraction but before purification steps. This is because deuterated internal standards are not biologically available and adding known amount of internal standards to sample aids compound quantification by comparing the peak areas of same analyte in deuterated and non-deuterated forms. The use of deuterated IsoPs is ideally of similar chemical structure as to the target molecule, or as close as possible if commercially unavailable, so as to mimic the ionization efficiency of analyte in the matrix. Of note, losses of deuterated internal standards during sample purification are taken into account for the calculation of final concentrations.

A large number of known IsoPs are present physiologically and increasing types of IsoP species were successfully detected through IsoP research. Especially $\mathrm{F}_{2}$-dihomoIsoPs and $\mathrm{F}_{4}$-NeuroPs molecules that arise from $\mathrm{AdA}$ and DHA, respectively, which are highly present in the brain
[46], and $\mathrm{F}_{3}$-IsoPs from EPA, were all recently reported to be quantifiable in human plasma (Table 3). Compared to $\mathrm{F}_{2}$-IsoPs from ARA, the concentrations of the IsoPs from ALA, EPA or DHA are very low but measurable by the GC-MS, GC-MS/MS, or LC-MS/MS.1

\section{Parameters to Consider on Using GC or LC Coupled to MS for Human Plasma IsoPs Measurement}

\section{Detection and Quantitation Limits}

The limit of detection (LOD) and limit of quantitation (LOQ) are two parameters most widely discussed in MS analytical methods. LOD and LOQ are closely related, but have different definitions and confusion must be avoided. LOD refers to the lowest analyte concentration detectable, but not necessarily quantifiable under the test condition, while LOQ refers to the lowest concentration of an analyte that can be determined with satisfactory precision and accuracy under the test condition. To find out the LOD and LOQ of an analyte, sufficient analytical signal must be instantly spotted out from the analytical noise, which is produced in the absence of analyte. More often than not, 
Table 3 Newly found isoprostanes in human plasma

\begin{tabular}{|c|c|c|c|c|c|c|}
\hline Isoprostanoid & Study & Purification & MS-method & $\begin{array}{l}\text { Mass spectrometer (com- } \\
\text { pany) }\end{array}$ & Levels detected $(\mathrm{pg} / \mathrm{mL})$ & References \\
\hline $\mathrm{F}_{2}$-Dihomo-IsoP & $\begin{array}{l}\text { Control } \\
\text { RTT }\end{array}$ & SPE: Sep-Pak C18 \& $\mathrm{NH}_{2}$ & GC-MS/MS & Polaris Q (ThermoFinnigan) & $\begin{array}{l}1.0 \pm 0.11(\text { free }) \\
3.3 \pm 0.31(\text { free })\end{array}$ & {$[50]$} \\
\hline \multirow[t]{2}{*}{$\mathrm{F}_{3}$-IsoPs ${ }^{\mathrm{a}}$} & $\begin{array}{l}\text { Control } \\
\text { RTT }\end{array}$ & SPE: Sep-Pak C18 \& NH & GC-MS/MS & Polaris Q (ThermoFinnigan) & $\begin{array}{l}13 \text { (free) } \\
40 \text { (free) }\end{array}$ & {$[58]$} \\
\hline & $\begin{array}{l}\text { No PoAF } \\
\text { PoAF }\end{array}$ & $\begin{array}{l}\text { TLC: 60ALK6D plates \& } \\
\text { SPE: C18 Sep-Pak }\end{array}$ & GC-MS/MS & HP 5973 N (Agilent) & $\begin{array}{l}5 \text { (total) } \\
6 \text { (total) }\end{array}$ & {$[57]$} \\
\hline $\mathrm{F}_{4}$-NeuroP & $\begin{array}{l}\text { Control } \\
\text { Smokers }\end{array}$ & SPE: MAX & GC-MS & HP 5973 N (Agilent) & $\begin{array}{l}250 \pm 110(\text { total }) \\
460 \pm 200(\text { total })\end{array}$ & {$[62]$} \\
\hline
\end{tabular}

RTT Rett syndrome, PoAF post-operative atrial fibrillation, $T L C$ thin lay chromatography, SPE solid phase extraction, Sep-Pak C18 octadecylsilane cartridge, $\mathrm{NH}_{2}$ aminopropyl cartridge, $\mathrm{MAX}$ mixed anionic exchange

a Estimated values from graphical depiction in the report

the signal-to-noise ratio $(\mathrm{S} / \mathrm{N})$ is used in calculating their respective LOD and LOQ. A S/N greater than three is generally acceptable as LOD and S/N of at least ten for LOQ is commonly practised.

Diverse levels of LOD and LOQ were reported for the same analyte measured by different GC-MS or LC-MS/ MS models of different companies. For example, Haschke et al. [70] reported the measurement of $15-\mathrm{F}_{2 \mathrm{t}}$-IsoP in human plasma via QTRAP 4000 (ABSciex, USA) and QTRAP 5000 MS (ABSciex, USA) machines and found four-fold improvement for LOD in QTRAP 5000, suggesting that the latter model of the MS machine might be a better tool in compound analysis. We investigated highly cited articles in the Web of Science (Thomson Reuters) reporting on the detection of IsoPs (mainly $15-\mathrm{F}_{2 \mathrm{t}}$-IsoPs) in plasma using GC- and LC-coupled MS, respectively (Tables 1, 2). It suggests that the LOD and LOQ levels are of far superior for GC- than LC-coupled MS and the difference is the enhancement by GC derivatization, which will be discussed below. Comparatively, from Tables 1 and 2, LOD for LC-MS(/MS) seemed to perform better than GC-MS(/ MS). However, the S/N used by different groups for the stated LOD were not in coherence, implying that the LOD reported might not be comparable with others.

\section{Derivatization}

A distinct difference in employing GC or LC coupled MS is the need to derivatize the sample. Derivatization is needed in GC-MS(/MS), but not necessarily so for LCMS(/MS). The need to derivatize compound is to improve volatility for GC separation by adding chemical functions to its native structure, as well as increase thermal stability. However, the downside of performing derivatization is more labour intensive as well as exposure to potentially toxic chemicals. Different derivatization agents are available in the market and its suitability is based on which targeted compounds are being analysed.

Commonly, the three types of derivatization reactions for GC are silylation, acylation, and alkylation. Silylation is typically used for the detection of IsoPs in GC-MS. As illustrated in Fig. 1 the typical steps in derivatizing $15-\mathrm{F}_{2 \mathrm{t}^{-}}$ IsoP for $\mathrm{GC}-\mathrm{MS}$ analysis is shown [71]. Briefly, $15-\mathrm{F}_{2 \mathrm{t}^{-}}$ IsoP is converted to pentafluorobenzyl (PFB) esters by the means of pentafluorobenzyl bromide (PFBBr), followed by the use of derivatization agents $N, O$-bis (trimethylsilyl) trifluoroacetamide (BSTFA) and trimethylchlorosilane (TMCS). BSFTA readily silylate alcohol groups and TMCS act as a silylation catalyst to increase reactivity of BSTFA. It should be noted that the use of BSFTA + TMCS is extremely sensitive to moisture and, therefore, should be handled under dry conditions.

The use of derivatization reagents was also reported for LC-MS/MS platform. Simultaneous detection of multiple IsoPs is often performed under negative ionization mode, which has low ionization efficiency because free carboxylic acids are difficult to be detected, especially in large number of carboxylic acid-containing analytes. The derivatization of IsoP compatible for positive ionization is designed to overcome such inefficiencies. For example, Bollinger et al. [72] introduced a derivatization strategy that converts the carboxy moiety of oxylipins to an amide with positively charged $\mathrm{N}$-(4-aminomethylphenyl) pyridinium (AMPP). They reported the improvement of ionization efficiency and approximately 10-20-fold enhancement in detection sensitivity of derivatized eicosanoids [72, 73] and fourfold for $4(R S)-4-\mathrm{F}_{4 \mathrm{t}}-\mathrm{NeuroP}$ in human plasma (unpublished data) (Fig. 2a). The AMPP derivatizing agent is now commercialized by Cayman Chemical (USA) as $\mathrm{AMP}^{+}$Mass Spectrometry kit. Nevertheless, as mentioned by Bollinger and co-workers [73] and others [74], the product mass ion of AMPP-derivatized eicosanoids was consistently reported 

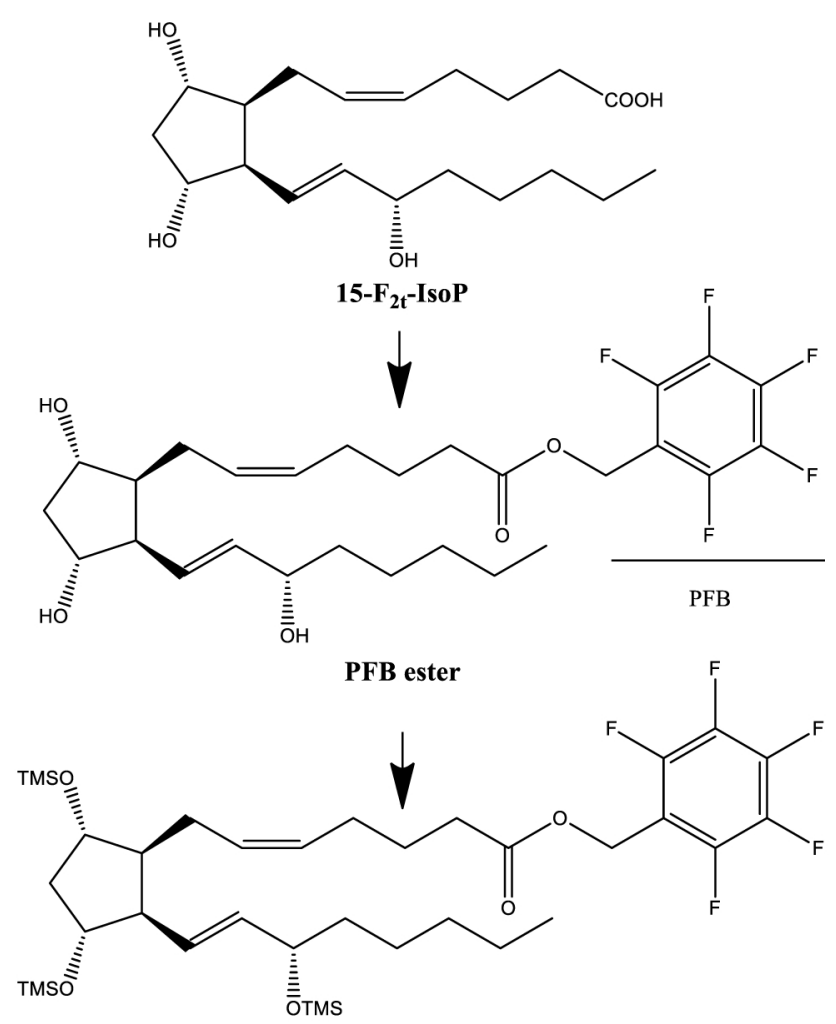

TMS derivative

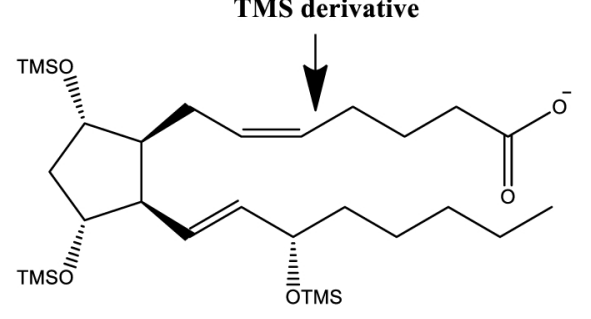

Derivatized 15-F $2 \mathrm{t}^{-}$IsoP, m/z 569

Fig. 1 Two derivatization steps for $15-\mathrm{F}_{2 \mathrm{t}}$-IsoP analyses by GC-MS. First derivatization is with pentafluorobenzyl bromide for the formation of pentafluorobenzyl (PFB) ester with $15-\mathrm{F}_{2 \mathrm{t}}$-IsoP and second derivatization is with $\mathrm{N}, \mathrm{O}$-bis(trimethylsilyl)trifluoroacetamide (BSTFA) to form pentafluorobenzyl ester-trimethylsilyl ether

to be $m / z 183$ and $m / z 169$ with high intensity, which are the AMPP derivative fragments (Fig. 2b). However, the group also indicated for this reason, certain compounds e.g. $\mathrm{PGF}_{2 \alpha}$ and arachidonic acid were measured by using a fragment in the analyte portion rather than the AMPP tag, i.e. non-tag fragment ion derived by cross-ring cleavage of the cyclopentanone ring. The application of AMPP eliminates the advantages of using the two-stage tandem MS as one is unable to identify the unique Q3 mass ion, in particular for IsoPs, that is derived from the analyte portion instead of the AMPP tag; especially when the MS machine loses its sensitivity when used extensively. Also, derivatization might affect the hydrophobicity of analyte causing retention time shift when passed through a HPLC column.
Fig. 2 Derivatization of carboxylic acid of isoprostanoids with $\mathrm{N}$-(4-aminomethylphenyl) pyridinium (AMPP) for LC-MS/MS analysis. The effect of AMPP is shown by chromatographic display (a) of human plasma for the measurement of $4(R S)-4-\mathrm{F}_{4 \mathrm{t}}-$ NeuroP with $(\mathrm{m} / \mathrm{z}, 545 \rightarrow 183)$ and without $(\mathrm{m} / \mathrm{z}, 377 \rightarrow 101)$ derivatization process; the response amplified approximately fourfold after derivatization (unpublished data). The formation of $\mathrm{m} / \mathrm{z}, 183$ (benzenemethanimine pyridinium ion) and 169 (tolylpyridinium distonic radical ion) products (b) in LC-MS/MS analysis serves as derivative fragments of carboxylic acid and does not alter for compounds with carboxylic acid group attached

Similarly, other derivatization compounds were reported for the use of lipid and their mediator detections in LCMS/MS system. For example, 2-(4-aminophenoxy)ethyl) (4-bromophenethyl)-dimethylammonium bromide hydrobromide (4-APEBA) was used to couple the carboxylic group of prostanoid molecules and measured at positive ionization mode. This method was found to be simple and able to enhance ESI efficiency in human urine analysis [75]. In a more recent study, N-hydroxysuccinimide (NHS) and 1-ethyl-3-[3-dimethylaminopropyl]-carbodiimide hydrochloride (EDC) were used to derivatize the carboxyl group of fatty acids in rat plasma and showed an increase in the sensitivity for LC-(ESI)MS/MS analysis as low as fentogram level [76]. Therefore, the use of derivatization may be a benefit in LC-MS/MS analysis using lower models (e.g. QTrap 3200) that are less sensitive for plasma IsoPs measurement (Fig. 2a), in which the levels normally range from picogram to nanogram per millilitre in healthy subjects; this allows better chromatographic peak detection for integration.

\section{Matrix Effects}

Matrix effect occurs when the compound of interest coelutes with other molecules from the column, almost exclusively in LC resulting in alteration of ionization efficiency. The possible phenomenon of matrix effects is signal suppression, reduction or even amplification. The exact mechanism of how matrix effects develops is unknown as the possible interacting molecules with the analyte in a matrix sample like plasma is affected in many ways. The current understanding of matrix effects is caused by the competition of non-volatile matrix components with analyte ions to retain at the surface of liquid droplet for transfer to the gas phase [77]. Analysis of multiple analytes under the same MS conditions might cause some, but not all analytes signals to be suppressed due to matrix effects [78].

The solution to reduce, but not remove matrix effects is switching the ionization source from ESI to APCI as some researchers found that under the APCI ionization mode, it appeared to be less severe [70, 79]. However, APCI mode 
A XIC of -MRM (48 pairs): 377.000/101.000 Da ID: 4(RS)-4-F4t-NeuroP

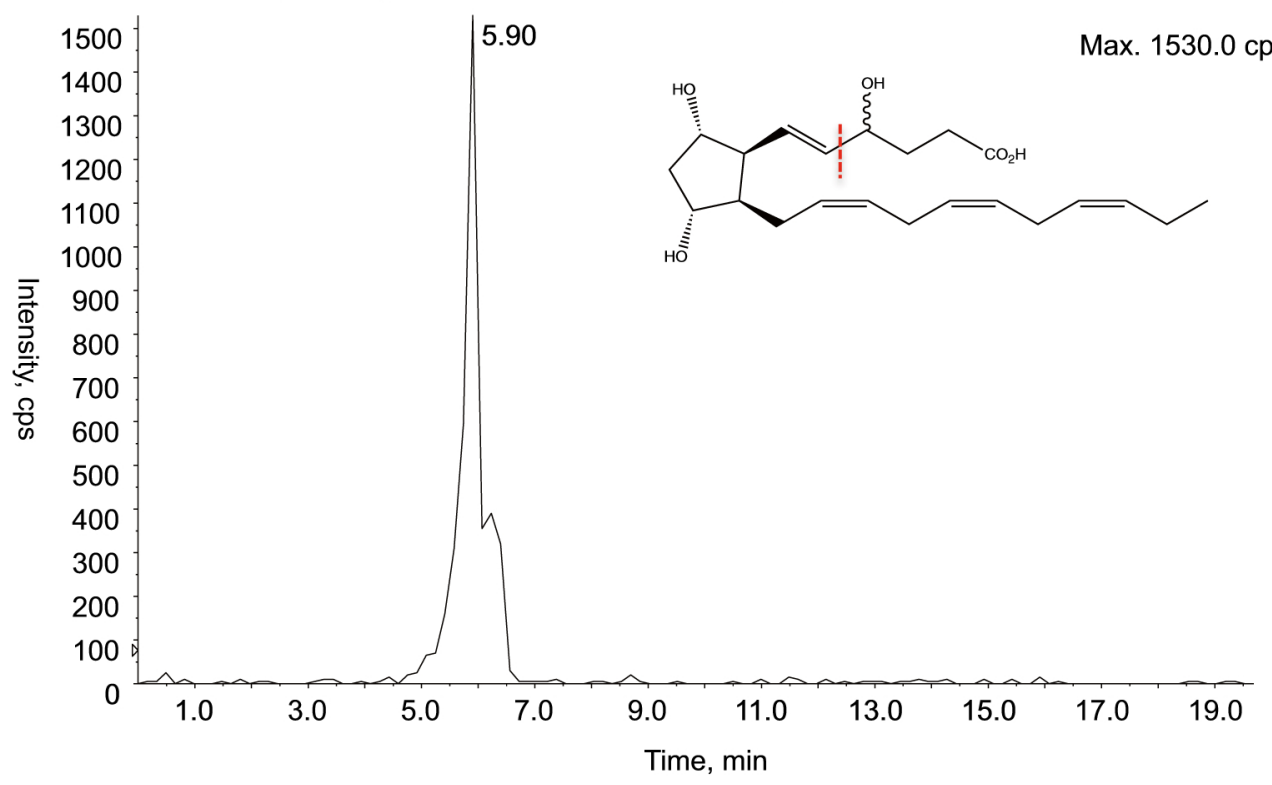

- XIC of +MRM (9 pairs): 545.000/183.000 Da ID: F4-NP

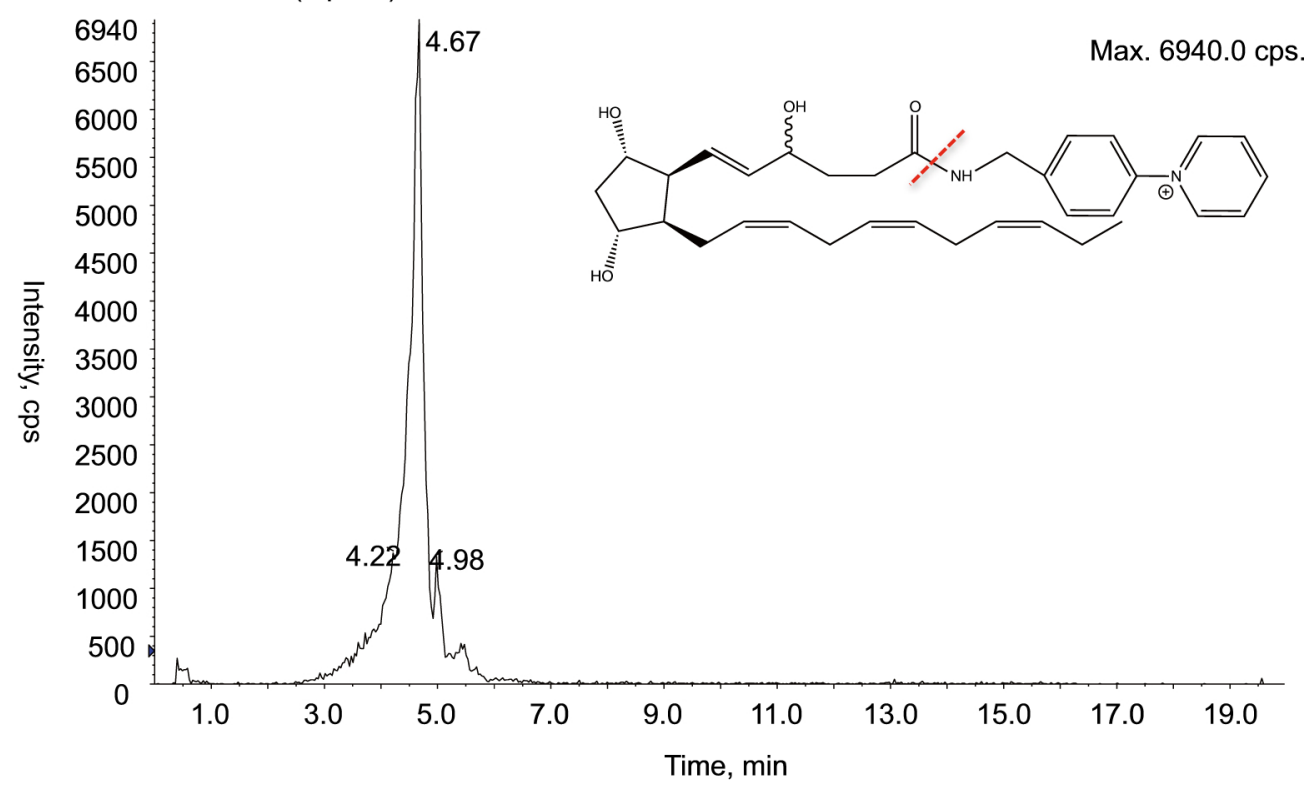

B

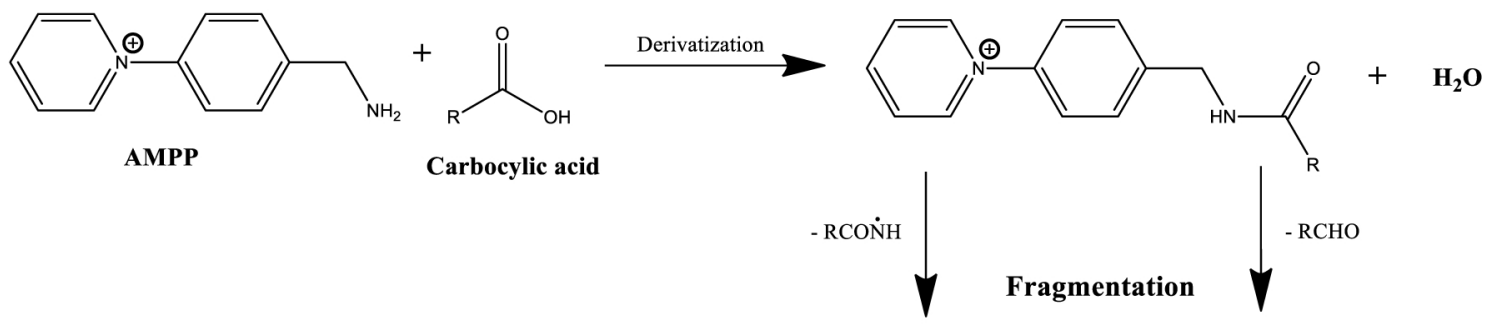

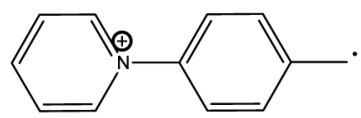

$\mathrm{m} / \mathrm{z} 169$

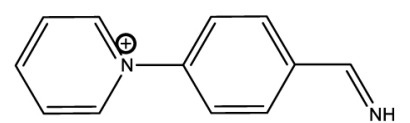

$\mathrm{m} / \mathrm{z} 183$ 
is not ideal to ionize IsoPs due to sample loss therefore, to reduce this effect, the interfering matrix components are often removed. Alternatively, protein precipitation by organic solvents is used to remove most of the dirtiest contaminants from the plasma matrix in the analysis for IsoPs. This is often followed by SPE or liquid-liquid extraction (LLE) purification. Some researchers also performed purification by on-line HPLC extraction prior to LC-MS/MS analysis using a column-switching device, which is advantageous over others for its automation in the analysis procedures $[80,81]$.

\section{Conclusions}

Given the relevance and emergence of lipid mediators in the field of lipidomics, the measurement of IsoPs molecules is essential in lipid research especially when investigating fatty acid metabolism and oxidative stress. The choice of whether GC- or LC-coupled MS technique for IsoPs measurement is one of the concerns by many, especially when the laboratory has access to both platforms. The design and development of GC is originally for the analysis of less polar and LC for more polar analytes. The measurement of human plasma IsoPs is possible in both platforms and the key is to ensure its sensitivity for measurement at very low concentrations. LC-MS/MS is gaining popularity in recent years for IsoPs detections and quantifications, offering a fast and highthroughput analysis with the help of MRM. Although MRM mode is also possible in the GC-MS/MS platform, the fragmented ions of most, if not all, analytes are the derivatives and therefore, reduce the advantages of using two-stage MS. Nonetheless, reducing matrix effects from plasma samples are often an obstacle when analysed by LC-MS(/MS). Appropriate clean-up procedures are necessary and derivatization for the analysis of less concentrated compounds are perhaps advantageous when subjecting the samples to LC-based MS analysis. However, due to some limitations in the use of GC- and LC-coupled MS platforms, as discussed in this article, one has to carefully consider the principle aim of the research project and decide on either platform depending on detectability, particularly when quantifying IsoPs that some are known to be low in abundance.

Acknowledgments We would like to thank Small Project Funding (201409176019) and the Seed Funding Program for Basic Research (201310159020), the University of Hong Kong for the support of this work.

\section{References}

1. Morrow JD, Harris TM, Roberts LJ 2nd (1990) Noncyclooxygenase oxidative formation of a series of novel prostaglandins: analytical ramifications for measurement of eicosanoids. Anal Biochem 184:1-10

2. Milne GL, Yin H, Hardy KD, Davies SS, Roberts LJ 2nd (2011) Isoprostane generation and function. Chem Rev 111:5973-5996

3. Jahn U, Galano JM, Durand T (2008) Beyond prostaglandinschemistry and biology of cyclic oxygenated metabolites formed by free-radical pathways from polyunsaturated fatty acids. Angew Chem 47:5894-5955

4. Milne GL, Dai Q, Roberts LJ 2nd (2015) The isoprostanes-25 years later. Biochim Biophys Acta 1851:433-445

5. Morrow JD, Hill KE, Burk RF, Nammour TM, Badr KF, Roberts LJ 2nd (1990) A series of prostaglandin F2-like compounds are produced in vivo in humans by a non-cyclooxygenase, free radical-catalyzed mechanism. Proc Natl Acad Sci USA 87:9383-9387

6. Roberts LJ, Morrow JD (2000) Measurement of F(2)-isoprostanes as an index of oxidative stress in vivo. Free Radic Biol Med 28:505-513

7. Sakamoto H, Corcoran TB, Laffey JG, Shorten GD (2002) Isoprostanes-markers of ischaemia reperfusion injury. Eur J Anaesthesiol 19:550-559

8. Davies SS, Traustadottir T, Stock AA, Ye F, Shyr Y, Harman SM, Roberts LJ 2nd (2009) Ischemia/reperfusion unveils impaired capacity of older adults to restrain oxidative insult. Free Radic Biol Med 47:1014-1018

9. Davies SS, Roberts LJ 2nd (2011) F2-isoprostanes as an indicator and risk factor for coronary heart disease. Free Radic Biol Med 50:559-566

10. Pratico D, MY Lee V, Trojanowski JQ, Rokach J, Fitzgerald GA (1998) Increased F2-isoprostanes in Alzheimer's disease: evidence for enhanced lipid peroxidation in vivo. FASEB J 12:1777-1783

11. Montine TJ, Kaye JA, Montine KS, McFarland L, Morrow JD, Quinn JF (2001) Cerebrospinal fluid abeta42, tau, and f2-isoprostane concentrations in patients with Alzheimer disease, other dementias, and in age-matched controls. Arch Pathol Lab Med 125:510-512

12. Montine TJ, Montine KS, McMahan W, Markesbery WR, Quinn JF, Morrow JD (2005) F2-isoprostanes in Alzheimer and other neurodegenerative diseases. Antioxid Redox Signal 7:269-275

13. Rossner P Jr, Gammon MD, Terry MB, Agrawal M, Zhang FF, Teitelbaum SL, Eng SM, Gaudet MM, Neugut AI, Santella RM (2006) Relationship between urinary 15-F2t-isoprostane and 8-oxodeoxyguanosine levels and breast cancer risk. Cancer Epidemiol Biomark Prev 15:639-644

14. Yan W, Byrd GD, Ogden MW (2007) Quantitation of isoprostane isomers in human urine from smokers and nonsmokers by LC-MS/MS. J Lipid Res 48:1607-1617

15. Klawitter J, Haschke M, Shokati T, Klawitter J, Christians U (2011) Quantification of 15-F2t-isoprostane in human plasma and urine: results from enzyme-linked immunoassay and liquid chromatography/tandem mass spectrometry cannot be compared. Rapid Commun Mass Spectrom 25:463-468

16. McKinney ET, Shouri R, Hunt RS, Ahokas RA, Sibai BM (2000) Plasma, urinary, and salivary 8-epi-prostaglandin f2alpha levels in normotensive and preeclamptic pregnancies. Am J Obstet Gynecol 183:874-877

17. Xie J, Zhang Q, Zhong N, Lai K (2009) BAL fluid 8-isoprostane concentrations in eosinophilic bronchitis and asthma. J Asthma 46:712-715

18. Halliwell B, Lee CY (2010) Using isoprostanes as biomarkers of oxidative stress: some rarely considered issues. Antioxid Redox Signal 13:145-156

19. Pratico D, Barry OP, Lawson JA, Adiyaman M, Hwang SW, Khanapure SP, Iuliano L, Rokach J, FitzGerald GA (1998) IPF2alpha-I: an index of lipid peroxidation in humans. Proc Natl Acad Sci USA 95:3449-3454 
20. Awad JA, Morrow JD, Takahashi K, Roberts LJ 2nd (1993) Identification of non-cyclooxygenase-derived prostanoid (F2-isoprostane) metabolites in human urine and plasma. J Biol Chem 268:4161-4169

21. Folch J, Lees M, Sloane Stanley GH (1957) A simple method for the isolation and purification of total lipides from animal tissues. J Biol Chem 226:497-509

22. Bligh EG, Dyer WJ (1959) A rapid method of total lipid extraction and purification. Can J Biochem Physiol 37:911-917

23. Zhang B, Saku K (2007) Control of matrix effects in the analysis of urinary F2-isoprostanes using novel multidimensional solidphase extraction and LC-MS/MS. J Lipid Res 48:733-744

24. Morrow JD, Minton TA, Mukundan CR, Campbell MD, Zackert WE, Daniel VC, Badr KF, Blair IA, Roberts LJ 2nd (1994) Free radical-induced generation of isoprostanes in vivo. Evidence for the formation of D-ring and E-ring isoprostanes. J Biol Chem 269:4317-4326

25. Walter MF, Blumberg JB, Dolnikowski GG, Handelman GJ (2000) Streamlined F2-isoprostane analysis in plasma and urine with high-performance liquid chromatography and gas chromatography/mass spectroscopy. Anal Biochem 280:73-79

26. Taber DF, Morrow JD, Roberts LJ 2nd (1997) A nomenclature system for the isoprostanes. Prostaglandins 53:63-67

27. Rokach J, Khanapure SP, Hwang SW, Adiyaman M, Lawson JA, FitzGerald GA (1997) Nomenclature of isoprostanes: a proposal. Prostaglandins 54:853-873

28. Morrow JD, Awad JA, Boss HJ, Blair IA, Roberts LJ 2nd (1992) Non-cyclooxygenase-derived prostanoids (F2-isoprostanes) are formed in situ on phospholipids. Proc Natl Acad Sci USA 89:10721-10725

29. Brose SA, Thuen BT, Golovko MY (2011) LC/MS/MS method for analysis of $\mathrm{E}(2)$ series prostaglandins and isoprostanes. $\mathrm{J}$ Lipid Res 52:850-859

30. Parchmann S, Mueller MJ (1998) Evidence for the formation of dinor isoprostanes E1 from alpha-linolenic acid in plants. $J$ Biol Chem 273:32650-32655

31. Cetin I, Alvino G, Cardellicchio M (2009) Long chain fatty acids and dietary fats in fetal nutrition. J Physiol 587:3441-3451

32. Barden AE, Croft KD, Durand T, Guy A, Mueller MJ, Mori TA (2009) Flaxseed oil supplementation increases plasma F1-phytoprostanes in healthy men. J Nutr 139:1890-1895

33. Collado-González J, Durand T, Ferreres F, Medina S, Torrecillas A, Gil-Izquierdo Á (2015) Phytoprostanes. Lipid Technol 27:127-130

34. Collado-Gonzalez J, Medina S, Durand T, Guy A, Galano JM, Torrecillas A, Ferreres F, Gil-Izquierdo A (2015) New UHPLCQqQ-MS/MS method for quantitative and qualitative determination of free phytoprostanes in foodstuffs of commercial olive and sunflower oils. Food Chem 178:212-220

35. Karg K, Dirsch VM, Vollmar AM, Cracowski JL, Laporte F, Mueller MJ (2007) Biologically active oxidized lipids (phytoprostanes) in the plant diet and parenteral lipid nutrition. Free Radic Res 41:25-37

36. Minghetti L, Salvi R, Lavinia Salvatori M, Ajmone-Cat MA, De Nuccio C, Visentin S, Bultel-Ponce V, Oger C, Guy A, Galano JM, Greco A, Bernardo A, Durand T (2014) Nonenzymatic oxygenated metabolites of alpha-linolenic acid B1- and L1-phytoprostanes protect immature neurons from oxidant injury and promote differentiation of oligodendrocyte progenitors through PPAR-gamma activation. Free Radic Biol Med 73:41-50

37. Leung KS, Chen X, Zhong W, Yu AC, Lee CY (2014) Microbubble-mediated sonoporation amplified lipid peroxidation of Jurkat cells. Chem Phys Lipids 180:53-60

38. Halliwell B, Grootveld M (1987) The measurement of free radical reactions in humans. Some thoughts for future experimentation. FEBS Lett 213:9-14
39. Ikizler TA, Morrow JD, Roberts LJ, Evanson JA, Becker B, Hakim RM, Shyr Y, Himmelfarb J (2002) Plasma F2-isoprostane levels are elevated in chronic hemodialysis patients. Clin Nephrol 58:190-197

40. Gopaul NK, Anggard EE, Mallet AI, Betteridge DJ, Wolff SP, Nourooz-Zadeh J (1995) Plasma 8-epi-PGF2 alpha levels are elevated in individuals with non-insulin dependent diabetes mellitus. FEBS Lett 368:225-229

41. Voutilainen S, Morrow JD, Roberts LJ 2nd, Alfthan G, Alho H, Nyyssonen K, Salonen JT (1999) Enhanced in vivo lipid peroxidation at elevated plasma total homocysteine levels. Arterioscler Thromb Vasc Biol 19:1263-1266

42. Morrow JD (2006) The isoprostanes-unique products of arachidonate peroxidation: their role as mediators of oxidant stress. Curr Pharm Des 12:895-902

43. Takahashi K, Nammour TM, Fukunaga M, Ebert J, Morrow JD, Roberts LJ 2nd, Hoover RL, Badr KF (1992) Glomerular actions of a free radical-generated novel prostaglandin, 8-epi-prostaglandin F2 alpha, in the rat. Evidence for interaction with thromboxane A2 receptors. J Clin Invest 90:136-141

44. Kinsella BT, O'Mahony DJ, Fitzgerald GA (1997) The human thromboxane $\mathrm{A} 2$ receptor alpha isoform (TP alpha) functionally couples to the $\mathrm{G}$ proteins $\mathrm{Gq}$ and $\mathrm{G} 11$ in vivo and is activated by the isoprostane 8-epi prostaglandin F2 alpha. J Pharmacol Exp Ther 281:957-964

45. VanRollins M, Woltjer RL, Yin H, Morrow JD, Montine TJ (2008) F2-dihomo-isoprostanes arise from free radical attack on adrenic acid. J Lipid Res 49:995-1005

46. de La Torre A, Lee YY, Oger C, Sangild PT, Durand T, Lee JC, Galano JM (2014) Synthesis, discovery, and quantitation of dihomo-isofurans: biomarkers for in vivo adrenic acid peroxidation. Angew Chem 53:6249-6252

47. Amir RE, Van den Veyver IB, Wan M, Tran CQ, Francke U, Zoghbi HY (1999) Rett syndrome is caused by mutations in $\mathrm{X}$-linked MECP2, encoding methyl-CpG-binding protein 2. Nat Genet 23:185-188

48. Leoncini S, De Felice C, Signorini C, Pecorelli A, Durand T, Valacchi G, Ciccoli L, Hayek J (2011) Oxidative stress in Rett syndrome: natural history, genotype, and variants. Redox Rep $16: 145-153$

49. Filosa S, Pecorelli A, D’Espositoc M, Valacchi G, Hajek J (2015) Exploring the possible link between MeCP2 and oxidative stress in Rett syndrome. Free Radic Biol Med 88:81-90

50. De Felice C, Signorini C, Durand T, Oger C, Guy A, BultelPonce V, Galano JM, Ciccoli L, Leoncini S, D'Esposito M, Filosa S, Pecorelli A, Valacchi G, Hayek J (2011) F2-dihomoisoprostanes as potential early biomarkers of lipid oxidative damage in Rett syndrome. J Lipid Res 52:2287-2297

51. Durand T, De Felice C, Signorini C, Oger C, Bultel-Ponce V, Guy A, Galano JM, Leoncini S, Ciccoli L, Pecorelli A, Valacchi G, Hayek J (2013) F(2)-Dihomo-isoprostanes and brain white matter damage in stage 1 Rett syndrome. Biochimie 95:86-90

52. Nourooz-Zadeh J, Halliwell B, Anggard EE (1997) Evidence for the formation of $\mathrm{F} 3$-isoprostanes during peroxidation of eicosapentaenoic acid. Biochem Biophys Res Commun 236:467-472

53. Chen CT, Domenichiello AF, Trepanier MO, Liu Z, Masoodi M, Bazinet RP (2013) The low levels of eicosapentaenoic acid in rat brain phospholipids are maintained via multiple redundant mechanisms. J Lipid Res 54:2410-2422

54. Gao L, Yin H, Milne GL, Porter NA, Morrow JD (2006) Formation of F-ring isoprostane-like compounds (F3-isoprostanes) in vivo from eicosapentaenoic acid. J Biol Chem 281:14092-14099

55. Roy J, Oger C, Thireau J, Roussel J, Mercier-Touzet O, Faure D, Pinot E, Farah C, Taber DF, Cristol JP, Lee JC, Lacampagne A, Galano JM, Durand T, Le Guennec JY (2015) Nonenzymatic lipid mediators, neuroprostanes, exert the antiarrhythmic 
properties of docosahexaenoic acid. Free Radic Biol Med $86: 269-278$

56. Jamil J, Bankhele P, Salvi A, Mannix JE, Oger C, Guy A, Galano JM, Durand T, Njie-Mbye YF, Ohia SE, Opere CA (2014) Role of the non-enzymatic metabolite of eicosapentaenoic acid, 5-epi5 -F3t-isoprostane in the regulation of $[(3) \mathrm{H}]_{\mathrm{D}}$-aspartate release in isolated bovine retina. Neurochem Res 39:2360-2369

57. Wu JH, Marchioli R, Silletta MG, Masson S, Sellke FW, Libby P, Milne GL, Brown NJ, Lombardi F, Damiano RJ Jr, Marsala J, Rinaldi M, Domenech A, Simon C, Tavazzi L, Mozaffarian D (2015) Oxidative stress biomarkers and incidence of postoperative atrial fibrillation in the omega- 3 fatty acids for prevention of postoperative atrial fibrillation (OPERA) Trial. J Am Heart Assoc 4:e001886

58. De Felice C, Signorini C, Durand T, Ciccoli L, Leoncini S, D'Esposito M, Filosa S, Oger C, Guy A, Bultel-Ponce V, Galano JM, Pecorelli A, De Felice L, Valacchi G, Hayek J (2012) Partial rescue of Rett syndrome by omega-3 polyunsaturated fatty acids (PUFAs) oil. Genes Nutr 7:447-458

59. Roberts LJ 2nd, Montine TJ, Markesbery WR, Tapper AR, Hardy P, Chemtob S, Dettbarn WD, Morrow JD (1998) Formation of isoprostane-like compounds (neuroprostanes) in vivo from docosahexaenoic acid. J Biol Chem 273:13605-13612

60. Montine KS, Quinn JF, Zhang J, Fessel JP, Roberts LJ 2nd, Morrow JD, Montine TJ (2004) Isoprostanes and related products of lipid peroxidation in neurodegenerative diseases. Chem Phys Lipids 128:117-124

61. Montine TJ, Quinn JF, Milatovic D, Silbert LC, Dang T, Sanchez S, Terry E, Roberts LJ 2nd, Kaye JA, Morrow JD (2002) Peripheral F2-isoprostanes and F4-neuroprostanes are not increased in Alzheimer's disease. Ann Neurol 52:175-179

62. Seet RC, Lee CY, Loke WM, Huang SH, Huang H, Looi WF, Chew ES, Quek AM, Lim EC, Halliwell B (2011) Biomarkers of oxidative damage in cigarette smokers: which biomarkers might reflect acute versus chronic oxidative stress? Free Radic Biol Med 50:1787-1793

63. Barden AE, Corcoran TB, Mas E, Durand T, Galano JM, Roberts LJ, Paech M, Muchatuta NA, Phillips M, Mori TA (2012) Is there a role for isofurans and neuroprostanes in pre-eclampsia and normal pregnancy? Antioxid Redox Signal 16:165-169

64. Oger C, Bultel-Ponce V, Guy A, Balas L, Rossi JC, Durand T, Galano JM (2010) The handy use of Brown's P2-Ni catalyst for a skipped diyne deuteration: application to the synthesis of a [D4]labeled F4t-neuroprostane. Chemistry 16:13976-13980

65. Taber DF, Reddy PG, Arneson KO (2008) A potential route to neuroprostanes and isoprostanes: preparation of the four enantiomerically pure diastereomers of 13-F4t-neuroP. J Org Chem 73:3467-3474

66. Guy A, Oger C, Heppekausen J, Signorini C, De Felice C, Furstner A, Durand T, Galano JM (2014) Oxygenated metabolites of n-3 polyunsaturated fatty acids as potential oxidative stress biomarkers: total synthesis of 8-F3t-IsoP, 10-F4t-NeuroP and [D4]10-F4t-NeuroP. Chemistry 20:6374-6380

67. Quan LG, Cha JK (2002) Preparation of isoprostanes and neuroprostanes. J Am Chem Soc 124:12424-12425

68. Kim S, Lawson JA, Praticò D, FitzGerald GA, Rokach J (2002) The first total synthesis of iPF4 $\alpha$-VI and its deuterated analog. Tetrahedron Lett 43:2801-2805

69. Yang K, Han X (2011) Accurate quantification of lipid species by electrospray ionization mass spectrometry-meet a key challenge in lipidomics. Metabolites 1:21-40

70. Haschke M, Zhang YL, Kahle C, Klawitter J, Korecka M, Shaw LM, Christians U (2007) HPLC-atmospheric pressure chemical ionization MS/MS for quantification of 15-F2t-isoprostane in human urine and plasma. Clin Chem 53:489-497
71. Milne GL, Gao B, Terry ES, Zackert WE, Sanchez SC (2013) Measurement of F2- isoprostanes and isofurans using gas chromatography-mass spectrometry. Free Radic Biol Med 59:36-44

72. Bollinger JG, Thompson W, Lai Y, Oslund RC, Hallstrand TS, Sadilek M, Turecek F, Gelb MH (2010) Improved sensitivity mass spectrometric detection of eicosanoids by charge reversal derivatization. Anal Chem 82:6790-6796

73. Bollinger JG, Naika GS, Sadilek M, Gelb MH (2013) LC/ESIMS/MS detection of FAs by charge reversal derivatization with more than four orders of magnitude improvement in sensitivity. $\mathrm{J}$ Lipid Res 54:3523-3530

74. Liu X, Moon SH, Mancuso DJ, Jenkins CM, Guan S, Sims HF, Gross RW (2013) Oxidized fatty acid analysis by charge-switch derivatization, selected reaction monitoring, and accurate mass quantitation. Anal Biochem 442:40-50

75. Kretschmer A, Giera M, Wijtmans M, de Vries L, Lingeman H, Irth H, Niessen WM (2011) Derivatization of carboxylic acids with 4-APEBA for detection by positive-ion LC-ESI-MS(/MS) applied for the analysis of prostanoids and NSAID in urine. J Chromatogr B Analyt Technol Biomed Life Sci 879:1393-1401

76. Cai T, Ting H, Xin-Xiang Z, Jiang Z, Jin-Lan Z (2014) HPLCMRM relative quantification analysis of fatty acids based on a novel derivatization strategy. Analyst 139:6154-6159

77. King R, Bonfiglio R, Fernandez-Metzler C, Miller-Stein C, Olah $T$ (2000) Mechanistic investigation of ionization suppression in electrospray ionization. J Am Soc Mass Spectrom 11:942-950

78. Dams R, Huestis MA, Lambert WE, Murphy CM (2003) Matrix effect in bio-analysis of illicit drugs with LC-MS/MS: influence of ionization type, sample preparation, and biofluid. J Am Soc Mass Spectrom 14:1290-1294

79. Souverain S, Rudaz S, Veuthey JL (2004) Matrix effect in LCESI-MS and LC-APCI-MS with off-line and on-line extraction procedures. J Chromatogr A 1058:61-66

80. Pascoe R, Foley JP, Gusev AI (2001) Reduction in matrix-related signal suppression effects in electrospray ionization mass spectrometry using on-line two-dimensional liquid chromatography. Anal Chem 73:6014-6023

81. Wang S, Li J, Shi X, Qiao L, Lu X, Xu G (2013) A novel stopflow two-dimensional liquid chromatography-mass spectrometry method for lipid analysis. J Chromatogr A 1321:65-72

82. Mori TA, Croft KD, Puddey IB, Beilin LJ, Mori TA, Croft KD, Puddey IB, Beilin LJ (1999) An improved method for the measurement of urinary and plasma F2-isoprostanes using gas chromatography-mass spectrometry. Anal Biochem 268:117-125

83. Nourooz-Zadeh J, Gopaul NK, Barrow S, Mallet AI, Anggard EE (1995) Analysis of F2-isoprostanes as indicators of nonenzymatic lipid peroxidation in vivo by gas chromatographymass spectrometry: development of a solid-phase extraction procedure. J Chromatogr B Biomed Appl 667:199-208

84. Lee CY, Huang SH, Jenner AM, Halliwell B (2008) Measurement of F2-isoprostanes, hydroxyeicosatetraenoic products, and oxysterols from a single plasma sample. Free Radic Biol Med 44:1314-1322

85. Lee CY, Jenner AM, Halliwell B (2004) Rapid preparation of human urine and plasma samples for analysis of F2-isoprostanes by gas chromatography-mass spectrometry. Biochem Biophys Res Comm 320:696-702

86. Ohashi N, Yoshikawa M (2000) Rapid and sensitive quantification of 8-isoprostaglandin F2alpha in human plasma and urine by liquid chromatography-electrospray ionization mass spectrometry. J Chromatogr B Biomed Sci Appl 746:17-24

87. Taylor AW, Bruno RS, Frei B, Traber MG (2006) Benefits of prolonged gradient separation for high-performance liquid chromatography-tandem mass spectrometry quantitation of plasma total 15-series F-isoprostanes. Anal Biochem 350:41-51 
88. Sircar D, Subbaiah PV (2006) Isoprostane Measurement in Plasma and Urine by Liquid Chromatography-Mass Spectrometry with One-Step Sample Preparation. Clin Chem 53:251-258

89. Unterwurzacher I, Koal T, Bonn GK, Weinberger KM, Ramsay SL (2008) Rapid sample preparation and simultaneous quantitation of prostaglandins and lipoxygenase derived fatty acid metabolites by liquid chromatography-mass spectrometry from small sample volumes. Clin Chem Lab Med 46:1589-1597
90. Bastani NE, Gundersen TE, Blomhoff R (2009) Determination of 8-epi PGF2 concentrations as a biomarker of oxidative stress using triple-stage liquid chromatography/tandem mass spectrometry. Rapid Communications in Mass Spectrometry 23 (18):2885-2890 